\section{IJ§ER}

ISSN: 2149-5939
International Journal of Social Sciences and Education Research

Online, http://dergipark.gov.tr/ijsser

Volume: 4(3), 2018

\title{
The effect of commercial and social entrepreneurship motives on entrepre- neurial intention
}

\author{
Tülay Korkmaz Devrani ${ }^{1} \quad$ Selay Ilgaz Sümer ${ }^{2}$
}

Submission Date: 08 / 05 / 2018

Accepted Date: 01 / 07 / 2018

\begin{abstract}
Entrepreneurship is seen as one of the most notable concepts in recent years. The main purpose of this study is to examine students' commercial and social entrepreneurship motives (motive-based attributes) on their entrepreneurial intention. In the study, the effects of commercial and social entrepreneurship motives on entrepreneurial intention of the students were investigated. The sample was chosen by convenience sampling from the students of a private university in Ankara. The data obtained in the study were analyzed using SPSS. As a result, it was found that two sub-dimensions of commercial entrepreneurship motives (risk-taking and self-confidence), and one subdimension of social entrepreneurship motive (change-oriented) have significant effect on entrepreneurial intention.
\end{abstract}

Keywords: Commercial entrepreneurship motives, social entrepreneurship motives, entrepreneurial intention

\section{Introduction}

The concepts of entrepreneur and entrepreneurship are at the forefront of topics that have attracted considerable interest in recent years. The value of entrepreneurship is so much appreciated because of the contributions created.

There are many definitions in the literature about entrepreneur and entrepreneurship. The concept of an entrepreneur originating in French can be described as a person who takes part in the process of value creation by using the capital he owns (Damgacioğlu \& Uygun, 2011, p.20). Entrepreneurship is defined as "the process of creating value, establishing a new business or creating a new business or creating a new good or service (Bird, 1989)."

The entrepreneurial activities associated with the concepts of innovation and creativity are divided into a number of categories based on a number of criteria. The main types of entrepreneurship can be listed as follows (Apak, Taşcıyan \& Aksoy, 2010; Küçük, 2010):

- Social entrepreneurship

- Commercial entrepreneurship

- Opportunity entrepreneurship

- Intrapreneurship

- Woman entrepreneurship

- Serial entrepreneurship

${ }^{1}$ Dr., Baskent University, Ankara, Turkey, tkorkmaz@,baskent.edu.tr

2 Dr. Öğr. Üyesi, Baskent University, Ankara, Turkey, silgaz@baskent.edu.tr 
Devrani, T.K., Sümer, S.I. (2018). The effect of commercial and social entrepreneurship motives on entrepreneurial intention. International Journal of Social Sciences and Education Research, 4(3), 447 - 454.

The concepts of social and commercial entrepreneurship which are emphasized in this study are among the most important types of entrepreneurship. Social entrepreneurship includes entrepreneurial activities based on social issues. In other words, the main purpose of social entrepreneurship is; to be aware of the problems of social issues and to transform the capital that is owned based on innovation and creativity principles into investments that can contribute to social welfare and development (Kılıç Kırılmaz, 2014). Compared to other types of entrepreneurship, the main distinguishing feature of social entrepreneurship lies in the belief that profits are behind social benefits. In short, as stated by many authors in the literature, social entrepreneurship aims to initiate and sustain entrepreneurial activities within the framework of a social mission. On the other hand, commercial entrepreneurship, which is the focus of classical entrepreneurship activities, involves obtaining an economic value (Kılıç Kırılmaz, 2014). According to this, the main differences between social entrepreneurs and commercial (business) entrepreneurs can be listed as follows:

- The primary purpose of commercial entrepreneurship is to create an enterprise and gain commercial profit from it, while social entrepreneurship is a social change in the society.

- Profit is a gain in commercial entrepreneurship, while is a means in social entrepreneurship.

- In commercial entrepreneurship, entrepreneur takes the risk while in social entrepreneurship entrepreneurs take the risk on behalf of the stakeholders (Özdevecioğlu \& Cingöz, 2009, p.91).

This study was conducted to determine how commercial entrepreneurship motives and social entrepreneurship motives affect the entrepreneurial intention of the students. The study also investigates how the commercial and social entrepreneurship motives of university students differ according to their demographic characteristics. A part of the study is presented by Korkmaz Devrani \& Ilgaz Sümer in ICSSER-2018 Antalya.

\section{Literature}

In the literature characteristics of entrepreneurs are also examined. Nga \& Shamuganathan (2010) expressed some of the personality traits as agreeableness, openness and conscientiousness. They have associated these features with social entrepreneurship. Nga \& Shamuganathan called commercial entrepreneurship as the entrepreneurs who focused on short term opportunities. They expressed that financial returns are the sole purpose of commercial entrepreneurs. According to Brooks (2009), the basic characteristics of social entrepreneurs found as innovativeness, achievement centred, independence, sense of destiny, low risk aversion, tolerance for ambiguity and social value creation. Elkington \& Hartigan (2008) used the concept of "social change" while describing social entrepreneurs.

When the studies done in the literature are examined, it is seen that the concept of entrepreneurship is considered in one dimension and the difference of entrepreneurship and social entrepreneurship levels of the individuals is ignored. On the other hand, entrepreneurship can arise in different fields for different purposes. The sub-dimensions of social and commercial entrepreneurship can also affect entrepreneurial intention in different ways.

Research Question 1: Does commercial and social entrepreneurship motives affect students' entrepreneurial intention? 
Devrani, T.K., Sümer, S.I. (2018). The effect of commercial and social entrepreneurship motives on entrepreneurial intention. International Journal of Social Sciences and Education Research, 4(3), 447 - 454.

In the entrepreneurship literature, there are several studies evaluating the relationship between university students' entrepreneurship levels and their various demographic characteristics. In this context, Türkoğlu, Tetik \& Açıkgöz (2017) investigated the relationship between socio-demographic characteristics and entrepreneurial personality characteristics of vocational college students. As a result; it is concluded that there is a meaningful relationship between gender, age, academic program, class, type of education, personality characteristics, place of living, region and various family factors and entrepreneurial personality characteristics of students. Gümül, Çalık \& Kurt (2017) found that male students had more entrepreneurial tendencies, that the trend of entrepreneurship was the highest in the age group of 31-40, that the intention of entrepreneurship was increased when the family leader was an artisan. Yüksel, Cevher \& Yüksel (2015) determined that there is a significant relationship between gender and the professions of the families. Köksal \& Penez (2015) studied the demographic characteristics of university students and their intention towards the sector; gender, age, presence or absence of entrepreneurship in the family, and entrepreneurial intention. Büyükyılmaz, Karakaya \& Yıldıran (2015) reached the conclusion that there was no differentiation in entrepreneurial tendencies depending on age, work experience and the sector studied. However, it has been determined that the intention of entrepreneurship differs according to gender and academic programs seen in education. Çelik, İnce \& Bozyiğit (2014) concluded that as a result of the study conducted by university students, entrepreneurs in their families are willing to become entrepreneurs to determine the familial factors affecting their entrepreneurial intentions and that the educational status of the parents and the students had no relation to their intention to establish their own businesses in the future. Şeşen \& Basım (2012) determined that entrepreneurship intentions changed according to age, gender, work experience and monthly income of the family. On the other hand, Konaklığlu \& Kızanlıklı (2011) found that entrepreneurship tendencies differ according to the discipline, gender, work experience and field of study in which they are studying. As a result of studying with the aim of revealing the entrepreneurship tendencies of the students, Doğaner \& Altunoğlu (2010) have found that there is a relationship between gender and entrepreneurial tendencies but that there is no meaningful relationship between the educational levels of the students and entrepreneurship tendencies.

Research Question 2: Does the commercial and social entrepreneurship motives and entrepreneurial intention of university students differ according to their demographic characteristics?

\section{Methodology}

The authors examined the effects of the students' commercial and social entrepreneurship motives (motive-based attributes) on their entrepreneurial intention. The sample was selected from the students of a private university by convenience sampling in Ankara, Turkey. We selected students from regular classes; they participated in the study voluntarily. Analyses were conducted over 163 valid surveys. Table 1 contains the main characteristics of the participants.

The survey questionnaire has two sections. In the first part of the survey, there were questions which were aimed to determine the commercial and social entrepreneurship motives and entrepreneurial intention of the students. In the second part of the survey, participants were asked to determine the demographic characteristics of themselves and their families. We measured the commercial entrepreneurship motives on a 35-item scale based on Y1lmaz \& Sünbül's scale (2009). We measured the social entrepreneurship motives on a 10-item scale based on Carraher, Welsh \& Svilokos's scale (2016, p.392). The participants rated each item on a 5-point Likert type scale $(1=$ Never, $5=$ Always $)$. We measured the students' entrepreneurial intention with one item 
Devrani, T.K., Sümer, S.I. (2018). The effect of commercial and social entrepreneurship motives on entrepreneurial intention. International Journal of Social Sciences and Education Research, 4(3), 447 - 454.

("I will probably own my own business in the future"). The participants indicated their response on a 5 -point Likert scale $(1=$ Strongly Disagree, $5=$ Strongly Agree $)$.

Table 1. Frequencies of the demographic variables

\begin{tabular}{|c|c|c|}
\hline Gender & $\mathbf{n}$ & $\%$ \\
\hline Female & 75 & 46 \\
\hline Male & 88 & 54 \\
\hline \multicolumn{3}{|l|}{ Year of Study } \\
\hline Year 1 & 8 & 4.9 \\
\hline Year 2 & 73 & 44.8 \\
\hline Year 3 & 39 & 23.9 \\
\hline Year 4 & 43 & 26.4 \\
\hline \multicolumn{3}{|l|}{ Department } \\
\hline Management & 67 & 41.1 \\
\hline Economics & 36 & 22.1 \\
\hline Technology and Knowledge Management & 17 & 10.4 \\
\hline Computer Engineering & 18 & 11 \\
\hline Industrial Engineering & 11 & 6.7 \\
\hline Other & 9 & 5.7 \\
\hline \multicolumn{3}{|l|}{ Family Income } \\
\hline$<2000 \mathrm{TL}$ & 10 & 6.1 \\
\hline $2001-4000$ & 29 & 17.8 \\
\hline $4001-6000$ & 38 & 23.3 \\
\hline $6001-8000$ & 27 & 16.6 \\
\hline $8001-10000$ & 19 & 11.7 \\
\hline$>10001 \mathrm{TL}$ & 34 & 20.9 \\
\hline Missing & 6 & 3.7 \\
\hline \multicolumn{3}{|l|}{ Mother } \\
\hline Manager & 39 & 23.9 \\
\hline Not Manager & 124 & 76.1 \\
\hline \multicolumn{3}{|l|}{ Father } \\
\hline Manager & 92 & 56.4 \\
\hline Not Manager & 71 & 43.6 \\
\hline \multicolumn{3}{|l|}{ Favorite Entrepreneur } \\
\hline Elon Musk & 25 & 13.3 \\
\hline Steve Jobs & 9 & 5.5 \\
\hline My Father & 8 & 4.9 \\
\hline
\end{tabular}

We conducted an exploratory factor analysis to examine the structure of commercial and social entrepreneurship motives. Sampling adequacy was conducted using the Kaiser-Meyer-Olkin (KMO) analysis. Table 2 summarizes the KMO measurements and shows significant results for Bartlett's test of sphericity $(\mathrm{p}=0.00)$, which further supported sampling adequacy of the data. 
Devrani, T.K., Sümer, S.I. (2018). The effect of commercial and social entrepreneurship motives on entrepreneurial intention. International Journal of Social Sciences and Education Research, 4(3), 447 - 454.

Table 2. KMO and Bartlett's Test

\begin{tabular}{|l|c|c|}
\hline & $\begin{array}{l}\text { KMO measure of } \\
\text { sampling adequacy }\end{array}$ & $\begin{array}{l}\text { Bartlett's test of sphericity } \\
\text { (Sig.) }\end{array}$ \\
\hline Commercial entrepreneurship motives & 0.879 & .000 \\
\hline Social entrepreneurship motives & 0.784 & .000 \\
\hline
\end{tabular}

The factor analysis using Varimax with Kaiser Normalization rotation was done for these variable and factors with eigenvalues of greater than one were extracted and retained. In analyzing matrices, factors with loadings below 0.4 were suppressed. After cross-loaded items or lowloaded items were excluded, 24 items were retained based on the four-factor structure for the commercial entrepreneurship motives, 9 items were retained based on the two-factor structure for the social entrepreneurship motives. The factor analysis yielded 4 components with eigenvalues over 1, explaining $64.51 \%$ of the variance. According to the results of factor analysis, sub-dimensions of commercial entrepreneurship motives were labelled as "risk-taking", "openness to change", "self-confidence" and "struggle with difficulties". Two components of social entrepreneurship motives explained the $53.78 \%$ of the total variance. Sub-dimensions of social entrepreneurship motives were labelled as change-oriented motives and value-oriented motives. Table 3 shows that the results in the calculation of Cronbach Alpha coefficients of all dimensions were ranged from 0.69 (for openness to change) to 0.78 (for self-confidence). To study the correlation between variables, Pearson coefficient was selected as it was designed for interval level or continuous variables. All the sub-dimensions of commercial entrepreneurship motives and social entrepreneurship motives were significantly correlated to each other $(\mathrm{p}=.000)$. They were also positively correlated with entrepreneurial intention. Means and standard deviations of each dimension were also reported in Table 3.

Table 3. Means, standard deviations, reliabilities, and correlations among commercial and social entrepreneurship motives and entrepreneurial intention

\begin{tabular}{|l|c|c|c|c|c|c|}
\hline Struggle with Difficulties & $(.71)$ & & & & & \\
\hline Risk Taking & $.276^{* *}$ & $(.70)$ & & & & \\
\hline Self-Confidence & $.626^{* *}$ & $.467^{* *}$ & $(.78)$ & & & \\
\hline Openness to Change & $.609^{* *}$ & $.425^{* *}$ & $.592^{* *}$ & $(.69)$ & & \\
\hline Value-oriented & $.583^{* *}$ & $.262^{* *}$ & $.541^{* *}$ & $.461^{* *}$ & $(.73)$ & \\
\hline Change-oriented & $.590^{* *}$ & $.484^{* *}$ & $.641^{* *}$ & $.699^{* *}$ & $.593^{* *}$ & $(.77)$ \\
\hline Entrepreneurial Intention & $.254^{* *}$ & $.309^{* *}$ & $.338^{* *}$ & $.275^{* *}$ & $.092^{* *}$ & $.166^{*}$ \\
\hline Mean & 4.08 & 3.61 & 3.93 & 3.73 & 3.90 & 3.81 \\
\hline Standard deviation & .58 & .75 & .58 & .59 & .61 & .65 \\
\hline
\end{tabular}

*significant at 0.05 level

** significant at 0.01 level

Multiple regression analysis was used to test if the commercial and social entrepreneurship motives significantly predicted participants' entrepreneurial intention. The results of the regression indicated that the model was significant $\left(\mathrm{R}^{2}=.19, \mathrm{~F}(6.156)=6.07, \mathrm{p}<.01\right)$. It was found that risk-taking significantly predicted entrepreneurial intention $(\beta=.27, \mathrm{p}<.05)$, as did Self-Confidence $(\beta=.44, \mathrm{p}<.05)$. Change-oriented social entrepreneurship motive also affected entrepreneurial intention $(\beta=-.33, p<.10)$. Other dimensions have not significantly affected entrepreneurial intention. Regression analysis was shown in Table 4. 
Devrani, T.K., Sümer, S.I. (2018). The effect of commercial and social entrepreneurship motives on entrepreneurial intention. International Journal of Social Sciences and Education Research, 4(3), 447 - 454.

Table 4. Regression Analysis

\begin{tabular}{|c|c|c|c|}
\hline Model & $\beta$ & $\mathrm{t}$ & Sig \\
\hline (Constant) & 1.334 & 2.389 & .02 \\
\hline Struggle with Difficulties & .224 & 1.297 & 0.182 \\
\hline Risk taking & .274 & 2.590 & $.011 * *$ \\
\hline Self-confidence & .439 & 2.539 & $.012 * *$ \\
\hline Openness to change & .242 & 1.413 & .160 \\
\hline Value-oriented & -.197 & -1.339 & .182 \\
\hline Change-oriented & -.327 & -1.932 & $.055^{*}$ \\
\hline
\end{tabular}

*significant at 0.10 level

** significant at 0.05 level

The other findings of the study can be listed as below:

- There is a significant difference $(p<.05)$ in risk taking and openness to change between male and female students.

- There is no significant difference between male and female participants in struggle with difficulties and self-confidence.

- There is no significant difference between male and female participants in change-oriented and value-oriented entrepreneurship.

- There is a significant difference between second and fourth year students in risk taking. $(\mathrm{F}=4.73, \mathrm{p}<.01)$

- There is a significant difference between second and fourth year students in openness to change. $(\mathrm{F}=4.75, \mathrm{p}<.01)$

- Entrepreneurship tendencies of third-year students are found to be higher than those of second-year students. $(\mathrm{F}=4.51, \mathrm{p}<.01)$

- There is a positive correlation between family income and value-oriented social entrepreneurship $(\mathrm{r}=.16, \mathrm{p}<.05)$.

- There is a positive correlation between family income and entrepreneurial intention $(\mathrm{r}=.24$, $\mathrm{p}<.01)$.

- There is no significant difference for the entrepreneurial dimensions of the students according to whether their parents work in managerial position.

- The level of value-oriented social entrepreneurship differs according to whether or not parents are entrepreneurs $(\mathrm{p}<.10)$.

- The entrepreneurial intention is significantly different according to whether the father is manager or not.

- For the students whose father is in manager position, the entrepreneurial intention (mean=3.97) is higher than the father who is not (mean=3.70).

- There is no significant relationship between the general grade average of students and entrepreneurial intention.

\section{Conclusion}

Most of the studies in the literature ignore the thin line between commercial entrepreneurship and social entrepreneurship of the individuals. However, individuals may want to engage in entrepreneurial activities for different reasons. In this study entrepreneurship was addressed at two different types as social entrepreneurship and commercial entrepreneurship. The effects of two 
Devrani, T.K., Sümer, S.I. (2018). The effect of commercial and social entrepreneurship motives on entrepreneurial intention. International Journal of Social Sciences and Education Research, 4(3), 447 - 454.

types of entrepreneurship motives of the students on entrepreneurial intention were examined to understand which social or commercial entrepreneurship motives encourage students to be an entrepreneur.

According to the analysis results risk taking and self-confidence dimensions of commercial entrepreneurship motives were significantly related to students' entrepreneurial intention. Definitions in the literature emphasized the risk-taking dimension of entrepreneurship. The nature of entrepreneurship also implies uncertainty. Individuals who can cope with this uncertainty can pass on new business ideas. It is not surprising that the one of the important motivating factor in entrepreneurial intention is to take risks. Self-confidence is another motivation that causes individuals to engage in an entrepreneurial intention. It seems self-confidence individuals can take the bold steps necessary for entrepreneurship. From two sub-dimensions of social entrepreneurship motives "change-oriented motives" was found to be related with entrepreneurial intention. Individuals who are able to adapt easily to changes have an increasing entrepreneurial intention. Flexibility is one of the key in entrepreneurship.

Study results indicate that family related demographic factors have an important effect on students' entrepreneurial intention. The intention of entrepreneurship among the students differs according to whether or not their father is a manager or not. The response of "my father is my favorite entrepreneur" supports this result.

Entrepreneurship will continue to be one of the interesting topics to be followed in the literature in the coming years. This study is a preliminary work on determining the different motives that determine the entrepreneurship intention of university students. It is believed that the results of the study will shed light on new researches.

\section{References}

Apak, S., Taşciyan, K. H. \& Aksoy, M. (2010). Girişimcilik ve Sermaye Tedarik Yöntemleri. İstanbul: Papatya Yayıncilik.

Bird, B. J. (1989). Entrepreneurial Behavior. Illinois: Foresman and Company.

Brooks, A. C. (2009). Social Entrepreneurship: A modern approach to social venture creation. New Jersey: Pearson International Edition.

Büyükyılmaz, O., Karakaya, A. \& Yıldıran, C. (2015). Girişimcilik eğitimi alan bireylerin demografik özellikleri açısından girişimcilik eğilimleri arasındaki farklar. Girişimcilik ve Kalkınma Dergisi, 10(2), 105125.

Carraher, S. M., Welsh, D.H.B. \& Svilokos, A. (2016). Validation of a measure of social entrepreneurship. European Journal of International Management, special issue on internationalization of social entrepreneurship, 10(4), 386-402.

Çelik, A., İnce, M. \& Bozyiğit, S. (2014). Üniversite öğrencilerinin girişimcilik niyetlerini etkileyen ailesel faktörleri belirlemeye yönelik bir çalışma. Niğde Üniversitesi İktisadi ve İdari Bilimler Fakültesi Dergisi, 7(3), 113-124.

Damgacıŏlu, M. H. \& Uygun, R. (2011). Girişimcilik paradigmasında dönüşüm: Deneyime dayalı girişimci türleri üzerine teorik bir değerlendirme, Girişimcilik ve Kalkınma Dergisi, 6(2), 17-32.

Doğaner, M. \& Altunoğlu, A. E. (2010). Adnan Menderes Üniversitesi Nazilli İktisadi ve İdari Bilimler Fakültesi İşletme Bölümü öğrencilerinin girişimcilik eğilimleri. Organizasyon ve Yönetim Bilimleri Dergisi, 2(2), 103-110.

Elkington, J. \& P. Hartigan (2008). The power of unreasonable people. U.S.A.: Harvard Business Press. 
Devrani, T.K., Sümer, S.I. (2018). The effect of commercial and social entrepreneurship motives on entrepreneurial intention. International Journal of Social Sciences and Education Research, 4(3), 447 - 454.

Gümül, F., Çalık, A. \& Kurt, H. (2017). Meslek yüksekokulu öğrencilerinin girişimcilik eğilimlerini incelemeye yönelik bir araştırma. Afyon Kocatepe Üniversitesi Sosyal Bilimler Dergisi, 19(2), 91-107.

Kılıç Kırılmaz, S. (2014). Sosyal girişimcilik boyutlarına kuramsal bir bakış. Ekonomi ve Yönetim Araştırmaları Dergisi, 3(2), 55-74.

Konaklıŏlu, E. \& Kızanlıklı, M. M. (2011). Üniversite öğrencilerinin proaktif kişilik özellikleri ile girişimcilik eğilimleri arasındaki ilişki. Ticaret ve Turizm Eğitim Fakültesi Dergisi, 1, 72-92.

Korkmaz Devrani, T. \& Ilgaz Sümer, S. (2018). A research on commercial and social entrepreneurship of university students. 5th International Conference on Social Sciences and Education Research, April 20 22, Antalya.

Köksal, Y. \& Penez, S. (2015). Yüksek girişimcilik eğilimli üniversiteli gençlerin demografik özellikleri ve sektör tercihleri üzerine bir inceleme. Süleyman Demirel Üniversitesi İktisadi ve İdari Bilimler Fakültesi Dergisi, 20(1), 155-167.

Küçük, O. (2010). Girişimcilik ve Küçük İşletme Yönetimi. Ankara: Seçkin Yayıncılık.

Nga, J. K. H.\& Shamuganathan, G. (2010). The influence of personality traits and demographic factors on social entrepreneurship start up intentions. Journal of Business Ethics, 95, 259-282.

Özdevecioğlu, M. \& Cingöz, A. (2009). Sosyal girişimcilik ve sosyal girişimciler: Teorik çerçeve. Erciyes Üniversitesi İktisadi ve İdari Bilimler Fakültesi Dergisi, 32, 81-95.

Şeşen, H. \& Basım, N. (2012). Demografik faktörler ve kişiliğin girişimcilik niyetine etkisi: Spor bilimleri alanında öğrenim gören üniversite öğrencileri üzerine bir araştırma. Ege Akademik Bakış, 12, 21-28.

Türkoğlu, T., Tetik, S. \& Açıkgöz, A. (2017). Meslek yüksekokulu öğrencilerinin sosyo-demografik özellikleri ile girişimci kişilik özellikleri arasındaki ilişkinin araştırılması. Journal of Yaşar University, 12(45), 1-13.

Yılmaz, E. \& Sünbül, A. M. (2009). Üniversite öğrencilerine yönelik girişimcilik ölçeğinin geliştirilmesi. Selçuk Üniversitesi Sosyal Bilimler Enstitüsü Dergisi, 21, 195-203.

Yüksel, H., Cevher, E. \& Yüksel, M. (2015). Öğrencilerin girişimci kişilik özellikleri ile girişimcilik eğilimleri üzerine bir araştırma. Çankırı Karatekin Üniversitesi İktisadi ve İdari Bilimler Fakültesi Dergisi, 5(1), 143-156. 